\title{
Condom use and sexual partnerships among truck drivers in Southern Brazil
}

\author{
Daniela Knauth*, Andréa Fachel Leal, Flavia Pilecco \\ From $16^{\text {th }}$ International Symposium on HIV and Emerging Infectious Diseases \\ Marseille, France. 24-26 March 2010
}

\section{Background}

The truck drivers are a social group that is characterized by two things: be predominantly male and their itinerant character. These features provide a particular context to the experiences of gender and sexuality. This paper aims to demonstrate condom use and its relationship to the sexual partners of truck drivers.

\section{Methods}

The data analyzed are the result of a study conducted in five cities that concentrate a large number of truck drivers in southern Brazil. In the quantitative phase, 854 were interviewed truck drivers and qualitative phase were conducted semi-structured interviews with truck drivers and participant observation at gas stations.

\section{Results}

The truck mention the use of condoms, however there is a continued use, it depends on the partnership and the type of relationship. Thus, $68.8 \%$ of respondents claim to use condoms, always (36.5\%) or sometimes $(32.3 \%)$, but only $24.9 \%$ of them reported condom use at last intercourse. Those who used condoms in their relationship, did so with partners classified as sex worker (98.2\%) or possible (84.4\%). Condom use falls significantly with a primary partner (wife or girlfriend) to $14 \%$. Everyone recognizes that it is common to use the services of prostitutes in night parades. Approximately $57.4 \%$ of the subjects reported having used such services. Only $46.2 \%$ had condoms in the truck during the interview.

\section{Discussion}

Truck drivers are a very vulnerable group of STD/AIDS referred for engaging in risk associated with known

\footnotetext{
* Correspondence: daniela.knauth@gmail.com
}

UFRGS, Porto Alegre, Brazil infection, such as multiple sexual partners not associated with condom use and high use of alcohol and stimulants. While the high use of condoms, it occurs irregularly, depending on the type of partnership considered. Preventive actions should consider the character predominantly male and this itinerant population, with specific actions to stimulate prevention.

Published: 11 May 2010

doi:10.1186/1742-4690-7-S1-P126

Cite this article as: Knauth et al:: Condom use and sexual partnerships among truck drivers in Southern Brazil. Retrovirology 2010 7(Suppl 1): P126.
Submit your next manuscript to BioMed Central and take full advantage of:

- Convenient online submission

- Thorough peer review

- No space constraints or color figure charges

- Immediate publication on acceptance

- Inclusion in PubMed, CAS, Scopus and Google Scholar

- Research which is freely available for redistribution

Submit your manuscript at www.biomedcentral.com/submit
C Biomed Central 